Europe imported about 17.5 billion dollars worth of goods from overseas, against an export of only 5 billions. Foodstuffs and finished goods formed an unusually large proportion of these imports; the imports of raw materials were relatively small. Northern and western Europe received proportionately much larger supplies than central and eastern Europe. The import surplus was met mainly from shipping services (1.8 billion dollars), emigrants' allowances ( 1.4 billions), expenditures in Continental Europe of the American and British armies (about 1 billion), yield on foreign securities $(0.7$ billion), inter-governmental loans (about $2 \cdot 8$ billion, of which 0.9 billion were relief loans), liquidation of security portfolios, and to the extent of roughly 2.5 billions from short-term credits.

Food was supplied by relief organizations, mainly during the first half of 1919 , after which relief deliveries were on a much reduced scale. No international plan was evolved for the provision of the war areas with the other goods essential for the restoration of their economic life for nearly two years after the Armistice. The ter Meulen Plan, presented to the Brussels Conference in October 1920, for raw material credits, came too late and failed to materialize, and States were forced to acquire raw materials within the limits of their own financial capacities. The absence of provision for raw material credits was an essential factor in the process of currency depreciation, inflation and hyper-inflation. Inflation and currency depreciation in their turn caused a violent redistribution of national income and wealth, and prepared the ground for social unrest and political agitation. Action was only taken when inflation and the threat of social upheaval rendered it an unavoidable political necessity. This study gives a striking reminder of the magnitude of the disaster that resulted from the absence of any general plan, the failure of production and trade to revive, the social and political effects of inflation and the extent to which those effects were accentuated by the depression at the end of the first peace decade, and that depression accentuated by the burden of debt that Europe had assumed.

\section{Canadian Seed Potato Eye Trade}

$B y$ means of regulations issued in 1940, the Canadian Department of Agriculture exercises a strict control over the trade in seed potato eyes in the Dominion, where the raising of potato crops from eyes rather than from whole tubers is the usual practice in remote areas to which the transport of seed tubers is difficult. Eyes for sale must be cut only from certified seed, and their weight must be such that thirty-five eyes weigh not less than $1 \mathrm{lb}$. If the eyes are to be stored they are kept first for a week at $75^{\circ} \mathrm{F}$. to encourage cork formation, but subsequent storage is at lower temperatures. Eyes intended for dispatch to growers soon after being cut have the cut surface either dusted with limestone or waxed to prevent drying out. The eyes must be free from obvious fungal, bacterial and insect damage and must be shipped in specified types of cartons, and with each batch of eyes sold a copy of the directions for planting issued by the Department of Agriculture must be sent. The directions for planting indicate the desirability of planting the eyes as soon as they are received in moist soil and with adequate protection against drying out. If planted in dry soil the eyes may fail to develop. The recently described experiments at Kew suggest that some of the pre. cautions against drying out of the eyes may be unnecessary and that the use of controlled drying to produce 'dried potato eye chips' would further reduce the weight but not the viability of the eyes and so further simplify the difficulties of transport to remote areas.

\section{Treatment of Cancer}

THE annual report for 1943 of the British Empire Cancer Campaign directed attention to recent developments in the treatment of cancer. In particular, reference was made to encouraging work on the inhibition of cancer of the mammary gland and of the liver by diets; and that it has been possible to confirm statements of workers in the United States and Canada, who claimed that the symptoms of cancer of the prostate are inhibited by the administration, in the simple form of pills given by the moutn, of diethylstilbcestrol, a synthetic substance resembling other glandular products. This is a very great advance; but we shall do well to remember that, although diethylstilbœestrol relieves the symptoms of this form of cancer and makes the patient once more a useful citizen, its effects are not yet uniformly successful and no surgeon has yet claimed to cure cancer in this way. The treatment applies, moreover, to only one form of cancer. These cautions do not minimize the greatness of the advance; they are necessary only because the public is acutely sensitive to any statements about cancer research, and insists that it must not be misled about a subject which only the expert can properly understand.

The public is right to insist upon this. It should remember, nevertheless, that cancer research is still a charity mainly dependent upon the gifts of publicspirited individuals. These benefactors, as well as the general public, have a right to be sure that the work made possible by their gifts is well co-ordinated and properly controlled, and that its results are passed on to the public through the proper channels. A recent announcement issued by the British Empire Cancer Campaign will help to reassure them about this. The Campaign intends to keep practising medical men informed about the progress of cancer research, so that the public may have, through them, the advice of the Campaign's experts about suggested cancer treatments. The Campaign also intends to do all that it can to promote investigation into methods of treatment of cancer and into theories of its causation, stipulating only that full disclosure shall be made of the nature and method of use of suggested treatment, and so on. To these conditions no reasonable man can object. They are, in essence, the conditions which any scientific worker imposes upon himself whatever the nature of his scientific work may be.

\section{Malaria in the South-West Pacific}

A NEW campaign to combat malaria in the SouthWest Pacific is to be financed under the Colonial Development and Welfare Act, 1940, and an initial grant of $\$ 65,000$ to cover three years has been made for the purpose. The Anopheles mosquito, and consequently malaria, has hitherto been unknown in the territories of Fiji, Tonga, the Cook Islands, the Loyalty Islands, New Calodonia, the Gilbert and Ellice Islands and Samoa, In the islands to the west of Fiji, on the other hand, malaria is widely distributed. In peace-time, when there was little shipping traffic between the islands and air 